\title{
Is selective nodal irradiation in non-small cell lung cancer still safe when using IMRT? Results of a prospective cohort study
}

Citation for published version (APA):

Martinussen, H. M. A., Reymen, B., Wanders, R., Troost, E. G. C., Dingemans, A-M. C., Öllers, M. Houben, R., De Ruysscher, D., Lambin, P., \& van Baardwijk - Renkens, A. (2016). Is selective nodal irradiation in non-small cell lung cancer still safe when using IMRT? Results of a prospective cohort study. Radiotherapy and Oncology, 121(2), 322-327. https://doi.org/10.1016/j.radonc.2016.10.001

Document status and date:

Published: 01/11/2016

DOI:

10.1016/j.radonc.2016.10.001

Document Version:

Publisher's PDF, also known as Version of record

Document license:

Taverne

Please check the document version of this publication:

- A submitted manuscript is the version of the article upon submission and before peer-review. There can be important differences between the submitted version and the official published version of record.

People interested in the research are advised to contact the author for the final version of the publication, or visit the DOI to the publisher's website.

- The final author version and the galley proof are versions of the publication after peer review.

- The final published version features the final layout of the paper including the volume, issue and page numbers.

Link to publication

\footnotetext{
General rights rights.

- You may freely distribute the URL identifying the publication in the public portal. please follow below link for the End User Agreement:

www.umlib.nl/taverne-license

Take down policy

If you believe that this document breaches copyright please contact us at:

repository@maastrichtuniversity.nl

providing details and we will investigate your claim.
}

Copyright and moral rights for the publications made accessible in the public portal are retained by the authors and/or other copyright owners and it is a condition of accessing publications that users recognise and abide by the legal requirements associated with these

- Users may download and print one copy of any publication from the public portal for the purpose of private study or research.

- You may not further distribute the material or use it for any profit-making activity or commercial gain

If the publication is distributed under the terms of Article $25 \mathrm{fa}$ of the Dutch Copyright Act, indicated by the "Taverne" license above, 
Lung cancer IMRT

\title{
Is selective nodal irradiation in non-small cell lung cancer still safe when using IMRT? Results of a prospective cohort study ${ }^{\text {is }}$
}

\author{
Hanneke M.A. Martinussen ${ }^{\mathrm{a}, *}$, Bart Reymen ${ }^{a}$, Rinus Wanders ${ }^{\mathrm{a}}$, Esther G.C. Troost ${ }^{\mathrm{a}, \mathrm{d}, \mathrm{e}}$, \\ Anne-Marie C. Dingemans ${ }^{b}$, Michel Öllers ${ }^{a}$, Ruud Houben ${ }^{a}$, Dirk De Ruysscher ${ }^{\text {a,c }}$, Philippe Lambin ${ }^{\text {a }}$, \\ Angela van Baardwijk ${ }^{a}$
}

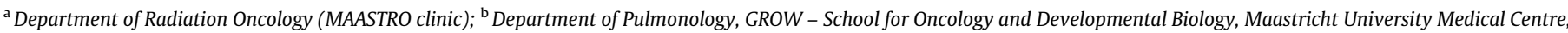

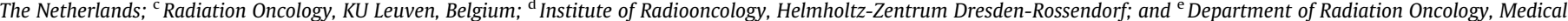
Faculty and University Hospital Carl Gustav Carus of Technische Universität Dresden, Germany

\section{A R T I C L E I N F O}

\section{Article history:}

Received 8 April 2016

Received in revised form 21 September

2016

Accepted 3 October 2016

Available online 21 November 2016

\section{Keywords:}

NSCLC

IMRT

Selective nodal irradiation

Isolated nodal failure

\begin{abstract}
A B S T R A C T
Background and purpose: Isolated nodal failures (INF) are rare after 3D-conformal radiotherapy (3D-CRT) for stage III non-small cell lung cancer (NSCLC). Since incidental nodal irradiation doses are lower with Intensity Modulated Radiation Therapy (IMRT) than with 3D-CRT, INF may be higher after IMRT. We therefore investigated the incidence of INF after IMRT in stage III NSCLC patients.

Materials and methods: Stage III NSCLC patients undergoing radical radiotherapy using IMRT in the period January 2010 till March 2012 were included. The primary endpoint was the rate of INF, secondary endpoints included patterns of failure, progression free survival (PFS), overall survival (OS) and toxicity. Results: 183 stage III NSCLC patients were enrolled. With a median follow-up of 58.0 months $2.2 \%$ of patients had an INF. The median PFS was 15.0 months, the median OS 19.5 months. Patterns of recurrence: $2.2 \%$ INF, $11.5 \%$ local and $2.7 \%$ loco-regional recurrence, $26.8 \%$ distant metastases only, $18.0 \%$ a combination of local/loco-regional and distant metastases, and 38.3\% patients without recurrence. One INF was out of field, in adjacent lymph nodes. Acute toxicity was limited.

Discussion: Selective nodal irradiation using IMRT in stage III NSCLC patients results in a low in-field incidence of INF (2.2\%), similar to 3D-CRT, and may thus be considered safe.
\end{abstract}

(C) 2016 Elsevier Ireland Ltd. All rights reserved. Radiotherapy and Oncology 121 (2016) 322-327
Lung cancer is one of the most frequently diagnosed solid tumours and the leading cause of cancer death [1,2]. Non-small cell lung cancer (NSCLC) accounts for about $80 \%$ of all lung cancer cases, and one third of the lung cancer patients presents with stage III disease [3]. The treatment of choice for most patients with stage III NSCLC is concurrent chemo-radiation [4-6].

Since local failure rates remain high after chemo-radiation, several strategies have been investigated to further improve local tumour control, including increasing the radiation dose $[7,8]$. The volume of the primary tumour and lymph seems to be associated with the probability of local and regional failure [9]. Selective nodal irradiation (SNI) instead of elective nodal irradiation (ENI)

\footnotetext{
Previous presentation: poster presentation at the ESTRO 33, Vienna in 2014

* Corresponding author.

E-mail addresses: hanneke.martinussen@maastro.nl (H.M.A. Martinussen), bart.reymen@maastro.nl (B. Reymen), rinus.wanders@maastro.nl (R. Wanders), esther.troost@uniklinikum-dresden.de (E.G.C. Troost), a.dingemans@mumc.nl (A.-M.C. Dingemans), michel.oellers@maastro.nl (M. Öllers), ruud.houben@maastro. nl (R. Houben), dirk.deruysscher@maastro.nl (D. De Ruysscher), philippe.lambin@ maastro.nl (P. Lambin), angela.vanbaardwijk@maastro.nl (A.van Baardwijk).
}

gives the opportunity to increase total tumour dose by decreasing the irradiated volume or to reduce toxicity [10-12]. Two prospective studies using 3D conformal radiotherapy (3D-CRT), in which selective nodal irradiation was based on PET-CT using 18Ffluorodeoxyglucose (FDG), showed only $2-2.3 \%$ isolated nodal failure (INF) [13,14]. Conversely, after ENI, INF ranged from 0.0 to $9.0 \%$ of the patients [15-17]. One of the reasons for the low percentages of INF with 3D-CRT may be the incidental dose given to adjacent lymph nodes, which may effectively eradicate microscopic metastases $[15,18,19]$. Other reasons may be that modern imaging and non-invasive staging has improved to such an extent that the rate of false negative nodes is so low that INF is a safe therapeutic strategy or that chemotherapy has eradicated nodal metastases.

IMRT is increasingly used in daily practice $[8,20-24]$. Studies suggest that IMRT in comparison to 3D-CRT delivers the dose more conformal to the target volume with a lower dose to the organs at risk [23,25-27]. However, IMRT leads to a significant lower incidental dose to adjacent lymph nodes as shown by Fleckenstein et al. [28]. If the adjacent lymph nodes contain microscopic metastasis, this lower dose may lead to a higher incidence of INF. 
Fleckenstein et al. estimated a tumour control probability of nodal stations of $23.6 \%$ with IMRT compared to $27.3 \%$ with 3D-CRT [28]. We therefore investigated the INF-rate in stage III NSCLC patients treated with IMRT.

\section{Materials and methods}

\section{Study population}

This study was approved by the Institutional Review Board of MAASTRO clinic (registration 13-18-17/07-intern-6915). For this current analysis we selected all patients who were treated with radical intent (concurrent or sequential with chemotherapy or radiotherapy (RT) alone) using IMRT in the period January 2010 till March 2012. Patients receiving chemotherapy concurrent with RT were included in a prospective observational study on the individualization of radiation dose (NCT00572325). Patients eligible for this analysis had histological and/or cytological confirmed stage IIIA and IIIB (Union for International Cancer Control, TNM 7th edition) NSCLC, less than $10 \%$ weight loss in six months, a World Health Organization Performance Status (WHO-PS) of $0-2$, a forced expiratory volume in one second $\left[\mathrm{FEV}_{1}\right] \geqslant 30 \%$ of the predicted value and a diffusion capacity of lungs for carbon monoxide [ $\mathrm{DL}_{\mathrm{CO}}$ ], not corrected for alveolar volume $\geqslant 30 \%$. Patients were excluded from this analysis if they had received surgery, or prior thoracic radiation.

\section{Treatment}

Patients received chemotherapy concurrently (conCRT) or sequentially (seqCRT) with RT or RT alone. In case of conCRT, chemotherapy consisted of cisplatin-etoposide (cisplatin 75$80 \mathrm{mg} / \mathrm{m}^{2}$ day 1 , etoposide $100 \mathrm{mg} / \mathrm{m}^{2}$ day $1-3$ ) or cisplatinvinorelbine (cisplatin $50 \mathrm{mg} / \mathrm{m}^{2}$ day 2 and $9,40 \mathrm{mg} / \mathrm{m}^{2}$ day 23; vinorelbine $20 \mathrm{mg} / \mathrm{m}^{2}$ day 2 and $9,15 \mathrm{mg} / \mathrm{m}^{2}$ day 23 and 30) every three weeks, administered with radiotherapy for three cycles. Radiotherapy was intended to start no later than the first day of the second cycle of chemotherapy. In case of seqCRT, chemotherapy consisted of three courses of gemcitabine $\left(1.250 \mathrm{mg} / \mathrm{m}^{2}\right.$ on days 1 and 8$)$ in combination with cisplatin $\left(75 \mathrm{mg} / \mathrm{m}^{2}\right.$ on day 1$)$ every three weeks. For both regimens standard dose-reduction rules were applied and cisplatin was substituted by carboplatin in case of renal impairment.

\section{Radiotherapy}

A FDG-PET-CT scan with low-dose CT for attenuation correction and an intravenous (iv) contrast-enhanced 4D-CT scan (Truepoint Biograph 40, Siemens, Erlangen, Germany) were performed for radiation planning purposes, and the delineation was based on fused imaging datasets. The total gross tumour volume (GTV) consisted of the primary tumour (GTV-1) delineated on the mid-ventilation CT scan fused with the PET-scan and the FDG-PET-positive and/or cytological proven malignant lymph nodes (GTV-2). A margin of $5 \mathrm{~mm}$ around the GTV was used to create the clinical target volumes, which were corrected for anatomical boundaries (CTV-1 and CTV-2, respectively). By adding a $10 \mathrm{~mm}$ margin to the CTV-1 and a $5 \mathrm{~mm}$ margin to the CTV-2 the planning target volume (PTV) was created. The volume of both lungs minus the total GTV was used for the calculation of the mean lung dose (MLD). Organs at risk were delineated: spinal cord (inner margin of the bony spinal canal), the oesophagus (outer contour from cricoid to gastro-oesophageal junction), brachial plexus and mediastinal structures (including great vessels, trachea, main bronchi and heart).

IMRT plans, were calculated according to the International Commission on Radiation Units and Measurement (ICRU, reports
50 and 62) standards using a superposition-convolution or an AAA algorithm, for a CMS XiO Radiotherapy Treatment Planning System (Xio, CMS, St Louis, MO).

Plans were optimized by direct machine parameter optimization with seven to nine coplanar and a maximum of two noncoplanar 6 and $10 \mathrm{MV}$ photon beams based on the location of the target volume. Every plan was created by using 10-15 segments per beam and involved a maximum of 25-35 iterations. Dose gradients in the PTV ranged from 90\% to $115 \%$ (preferably $95 \%$ to $115 \%$ ) of the prescribed dose, and $99 \%$ of the PTV ought to receive at least $90 \%$ of the prescribed dose.

Patients were irradiated on a linear accelerator (Siemens Oncor, Siemens Medical Solutions, Concord, CA) using Electronic Portal Imaging Device (EPID) measurements for treatment verification.

The radiation dose was individually escalated for all patients until one of the dose-limiting normal tissue constraints was reached: a maximum MLD of $20.0 \mathrm{~Gy}$, a maximum spinal cord dose (Dmax) of $54.0 \mathrm{~Gy}$, a Dmax to the brachial plexus of 70.0 Gy, a Dmax to mediastinal structures of $76.0 \mathrm{~Gy}$, mean dose (Dmean) to the heart of $46.0 \mathrm{~Gy}$ or a Dmax of $76.0 \mathrm{~Gy}$ to the oesophagus. With conCRT the maximum allowed total tumour dose (TTD) was $69.0 \mathrm{~Gy}$, delivered in $1.5 \mathrm{~Gy}$ fractions twice daily up to $45.0 \mathrm{~Gy}$, followed by $2-\mathrm{Gy}$ fractions once daily [29]. The maximum allowed TTD with seqCRT or RT alone was 79.2 Gy, given in twice daily fractions of $1.8 \mathrm{~Gy}$ [30]. Patients who were unable or not fit to be irradiated twice daily, were treated with once daily fractions of $2.75 \mathrm{~Gy}$ with a maximum TTD of 66.0 Gy. Constraints were recalculated to the equivalent dose in 2-Gy fractions (EQD2) and biological MLD [13,29,30].

\section{Endpoints}

The primary endpoint of this analysis was INF, and the secondary endpoints were patterns of failure, OS, PFS and toxicity. Follow-up was performed according to regional guidelines, consisting of a CT-scan with IV contrast 3 months after (C)RT, followed by regular X-rays of thorax and a yearly CT-scan. Additional imaging e.g. FDG-PET-CT scan was performed if clinically indicated. Imaging was used to determine local or regional disease progression or distant failure. If one or more of the following criteria were met, we scored it as a nodal failure: 1 . Lymph nodes that were pathologically proven to contain malignant cells after radiotherapy. 2. Enlarged lymphnode with increased uptake of $18 \mathrm{~F}-$ fluorodeoxyglucose on a FDG-PET-CT. 3. Lymph nodes that showed more than $20 \%$ growth after radiotherapy.

In case of a local or regional recurrence, the diagnostic images were compared with the radiation treatment plan. Local and nodal recurrences were considered in field if at least part of the recurrence disease volume was inside the original CTV and out of field if the recurrence was completely outside the original CTV. Out of field nodal recurrences were subdivided as recurrences in adjacent or non-adjacent lymph node stations, using the CT based atlas of Chapet et al. [31].

INF was defined as a recurrence in the regional lymph nodes without a synchronous local recurrence or distant metastases. Toxicity was scored according to the Common Terminology Criteria of Adverse Events (CTCAE) v. 4.0 by the radiation oncologist before start of radiotherapy, weekly during treatment and one month after radiotherapy. Last follow-up was on December 12th, 2015. The survival status was evaluated on December 15th, 2015 using a decentralized population registration system containing information about all inhabitants of the Netherlands.

\section{Statistical analysis}

The null hypothesis is that IMRT does not lead to more INF than 3D-CRT. Baseline INF with 3DCRT is $2.5 \%$. For the statistical 
analysis the SPSS software (IBM SPSS Statistics, Version 19.0, NY) was used. Patterns of recurrence were analyzed: the incidence of INF and the 2-year risk was calculated using the Kaplan-Meier method and Life-table analysis. For comparison of different treatment groups the Log-rank test was used.

OS was defined as the interval between pathological diagnosis and death or last follow-up using the Kaplan-Meier method. PFS was defined as the interval between pathological diagnosis and imaging showing local or regional progression, or distant metastases or death, whatever occurred first. For dyspnoea, cough and dysphagia grade 3 or more crude incidences were calculated. Results are expressed as mean or median \pm standard deviation (SD) or the $95 \%$ confidence interval (CI) and range.

\section{Results}

Between January 2010 and March 2012183 patients (119 males and 64 females) with a median age of $68.0 \pm 9.8$ years

Table 1

Patient, tumour and treatment characteristics.

\begin{tabular}{|c|c|c|}
\hline Characteristics & $\begin{array}{l}\text { No. of patients (\%) } \\
\text { concurrent }\end{array}$ & $\begin{array}{l}\text { No. of patients (\%), } \\
\text { sequential }\end{array}$ \\
\hline \multicolumn{3}{|l|}{ Age, years } \\
\hline Median & 66 & 74 \\
\hline Range & $34-85$ & $34-88$ \\
\hline \multicolumn{3}{|l|}{ Sex } \\
\hline Male & $73(62.4)$ & $32(71.1)$ \\
\hline Female & $44(37.6)$ & $13(28.9)$ \\
\hline \multicolumn{3}{|l|}{ WHO PS } \\
\hline 0 & 105 (89.7) & $29(64.4)$ \\
\hline 1 & $11(9.4)$ & $16(35.6)$ \\
\hline 2 & $1(0.9)$ & 0 \\
\hline \multicolumn{3}{|l|}{ Histology } \\
\hline SCC & $42(35.9)$ & $23(51.1)$ \\
\hline NSCLC NOS & $32(27.4)$ & $10(22.2)$ \\
\hline Adenocarcinoma & $27(23.1)$ & $9(20.0)$ \\
\hline Large cell & $14(12.0)$ & $3(6.7)$ \\
\hline Other & $2(1.6)$ & 0 \\
\hline \multicolumn{3}{|l|}{ Clinical stage } \\
\hline IIIA & $59(50.4)$ & $22(48.9)$ \\
\hline IIIB & $58(49.6)$ & $23(51.1)$ \\
\hline \multicolumn{3}{|l|}{ GTV in cc } \\
\hline Median & 70.3 & 42.6 \\
\hline Range & $2.8-1630.4$ & $9.6-1630.4$ \\
\hline \multicolumn{3}{|l|}{ Prescribed TTD, Gy } \\
\hline Median & 69.0 & 70.2 \\
\hline Range & $51-70.2$ & $20.4-73.8$ \\
\hline \multicolumn{3}{|l|}{ Delivered TTD, Gy } \\
\hline Median & 69.0 & 70.2 \\
\hline Range & $1.5-71.0$ & $45.6-73.8$ \\
\hline \multicolumn{3}{|l|}{ Dose limiting organ } \\
\hline TTD & $79(66.5)$ & $29(64.4)$ \\
\hline MLD & $23(19.7)$ & $10(22.2)$ \\
\hline Spinal cord & $9(7.7)$ & $1(2.2)$ \\
\hline $\begin{array}{l}\text { Mediastinal } \\
\text { structures }\end{array}$ & 0 & $1(2.2)$ \\
\hline Brachial plexus & $2(1.7)$ & 0 \\
\hline Unknown & $4(3.4)$ & $4(8.9)$ \\
\hline \multicolumn{3}{|l|}{ MLD, Gy } \\
\hline Median & 18.3 & 18.9 \\
\hline Range & $2.8-21.5$ & $11.0-22.9$ \\
\hline \multicolumn{3}{|l|}{ OTT, days } \\
\hline Median & 38 & 27 \\
\hline Range & $0-56$ & $19-98$ \\
\hline
\end{tabular}

WHO-PS = World Health Organisation Performance Score, GTV = total gross tumour volume, TTD = total tumour dose, MLD = mean lung dose, OTT = overall treatment time, $\mathrm{SCC}=$ squamous cell carcinoma, NOS $=$ not otherwise specified. (range 34-88) were treated with IMRT. Patient, tumour and treatment characteristics are presented in Table 1. Concurrent chemotherapy was given in 117 patients (63.9\%), while 45 patients (24.6\%) received induction chemotherapy followed by RT, and 21 patients (11.5\%) received RT only. The median delivered TTD was $69.0 \pm 9.3 \mathrm{~Gy}(1.5-73.8 \mathrm{~Gy})$ in a median overall treatment time (OTT) of $35.0 \pm 9.2$ days (1.0-56.0 days). The allowed maximum dose of $69.0 \mathrm{~Gy}$ was prescribed in $63.4 \%$ of the patients, in the other patients MLD was most often dose limiting (21.3\%). The median follow-up time was 58.0 months (95\% CI 55.8-60.3).

Only four patients (2.2\%) experienced an INF (actuarial 2-year risk 2.4\%; 95\% CI 0.0-5.7) of which three were in field recurrences and one was out of field. The patient with an out of field recurrence originally had pathologic lymph nodes in $6,5,4 \mathrm{~L}, 2 \mathrm{~L}$ and $1 \mathrm{~L}$ and had a recurrence in $1 R$.

One hundred and twelve patients (61.2\%) showed recurrent disease: $11.5 \%(n=21)$ local recurrence, $2.7 \%(n=5)$ loco-regional recurrence, $26.8 \%(n=49)$ distant metastases only and $18.0 \%$ ( $n=33)$ a combination of local/loco-regional recurrence and distant metastases. Of the local recurrences $85.7 \%$ was in field and $14.3 \%$ was out of field. Of all regional recurrences $63.3 \%$ was in field and $36.7 \%$ out of field. Of those out of field nodal recurrences, $27.3 \%$ $(n=3)$ occurred in an adjacent and $72.7 \%(n=8)$ in non-adjacent lymph node stations. An overview of the recurrences is presented in Table 2.

At the time of analysis 140 patients (76.5\%) had died. The median OS was 19.5 months (95\% CI 16.3-22.8 months), with a 1-year OS of $69.7 \%$ and a 2 -year OS of $42.3 \%$ (actuarial 2-year OS $41.0 \%$ ) for the entire group as depicted in Fig. 1. For the conCRT group the median OS was 20.8 months (95\% CI 16.6-25.2 months) and 16.0 months (95\% CI 10.8-21.2 months) for the seqCRT group $(p=0.13)$. The latter might be an overestimations as patients who had progressive disease after chemotherapy were excluded.

At the time of analysis, 112 patients (61.2\%) had developed recurrent disease. The median PFS was 15.0 months $(95 \% \mathrm{CI}$ 11.3-18.8 months) with a 1-year PFS of $60.0 \%$ and a 2 -year PFS of $35.2 \%$ (actuarial 2-year PFS 35\%) for the entire group (see Fig. 2). For the conCRT group the median PFS was 14.1 months $(95 \% \mathrm{CI}$

Table 2

Pattern of recurrences.

\begin{tabular}{ll}
\hline Recurrences & No. of patients (\%) \\
\hline None & $71(38.8)$ \\
Local & $21(11.5)$ \\
In field & 17 \\
Out of field & 4 \\
Isolated nodal & $4(2.2)$ \\
In field & 3 \\
Out of field & 1 \\
$\quad$ Adjacent lymph node station & 1 \\
$\quad$ Non-adjacent lymph node station & 0 \\
Loco-regional, with regard to nodal recurrences & $5(2.7)$ \\
In field & 3 \\
Out of field & 2 \\
Adjacent lymph node station & 0 \\
Non-adjacent lymph node station & 2 \\
Distant metastases & $49(26.8)$ \\
Combination, with regard to nodal recurrences & $33(18.0)$ \\
In field & 13 \\
Out of field & 8 \\
Adjacent lymph node station & 2 \\
Non-adjacent lymph node station & 6 \\
\hline
\end{tabular}

Local $=$ tumour recurrence, isolated nodal $=$ nodal recurrence, loco-regional $=$ tumour and nodal recurrence, combination = distant metastases with tumour and/or nodal recurrence. 


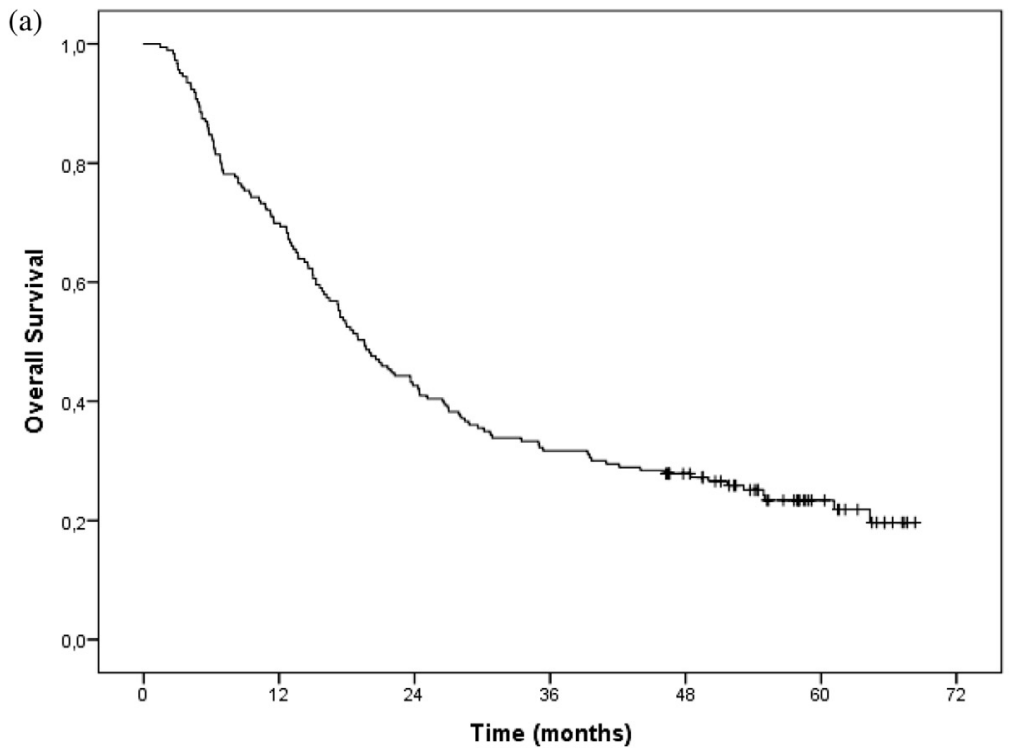

\begin{tabular}{|l|cccccc|}
\hline Time (months) & 0 & 12 & 24 & 36 & 48 & 60 \\
Number at risk & 183 & 128 & 78 & 58 & 45 & 16 \\
\hline
\end{tabular}

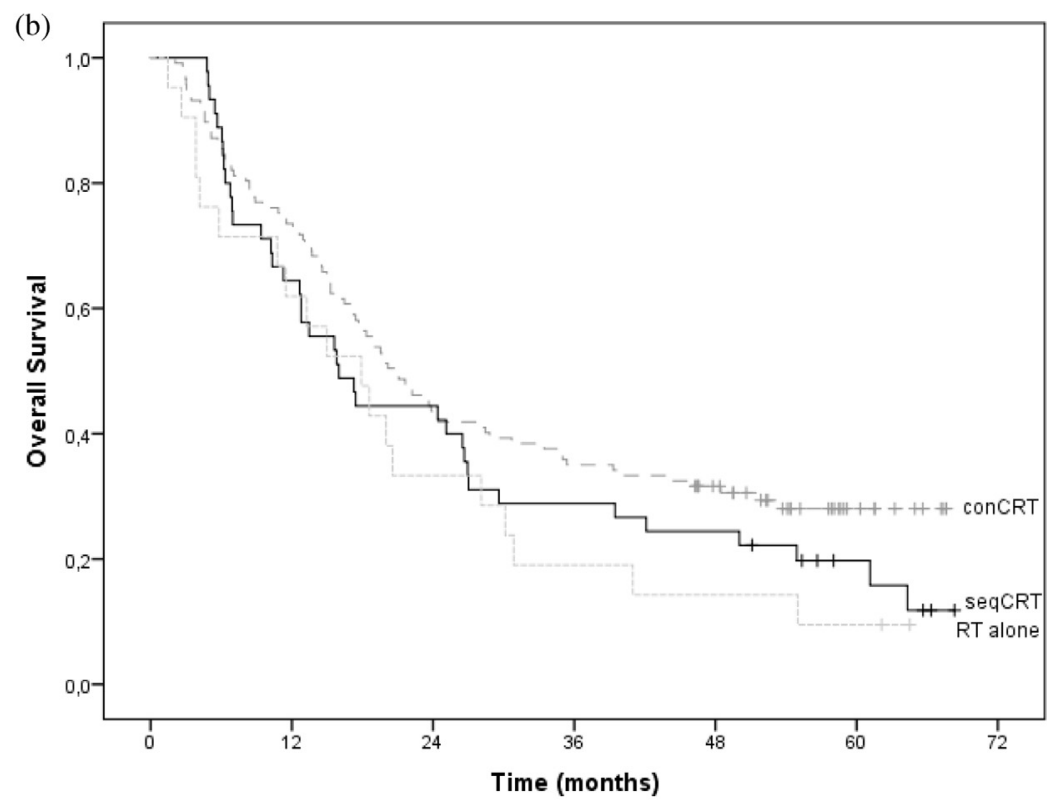

\begin{tabular}{|l|cccccc|}
\hline Time (months) & 0 & 12 & 24 & 36 & 48 & 60 \\
Number at risk conCRT & 116 & 86 & 51 & 41 & 31 & 9 \\
Number at risk seqCRT & 44 & 29 & 22 & 13 & 11 & 5 \\
Number at risk RT alone & 20 & 13 & 7 & 4 & 3 & 2 \\
\hline
\end{tabular}

Fig. 1. Kaplan-Meier curves showing Overall Survival (OS) for the entire cohort (a) and separated for concurrent, sequential and radiotherapy alone (b).

9.3-18.9 months) versus 15.7 months (95\% CI 6.5-24.8 months) for the seqCRT group $(p=0.63)$.

Before start of RT none of the patient had developed severe toxicity ( $\geqslant$ grade 3 ). During radiotherapy most patients had no (10.6\%) or only mild dysphagia (grade $1: 26.7 \%$, grade $2: 47.2 \%$ ), whereas in $15.5 \%$ of the patients grade 3 dysphagia occurred (conCRT $17.5 \%$, seqCRT $15.6 \%$, RT alone $4.8 \%$ ). One month after radiotherapy 17 patients had persistent severe dysphagia [15 patients (11.5\%) grade
3 , two patients (1.5\%) grade 4]. These complaints resolved in eleven of these patients, the grade was unclear in three patients three months after radiotherapy, and three patients died before reaching three months after radiotherapy.

Severe dyspnoea was not observed during radiotherapy, but one month after radiotherapy four patients (3.1\%) suffered from grade 3 dyspnoea. Three of these patients died within four months after radiotherapy and in one patient grade 3 dyspnoea persisted more 


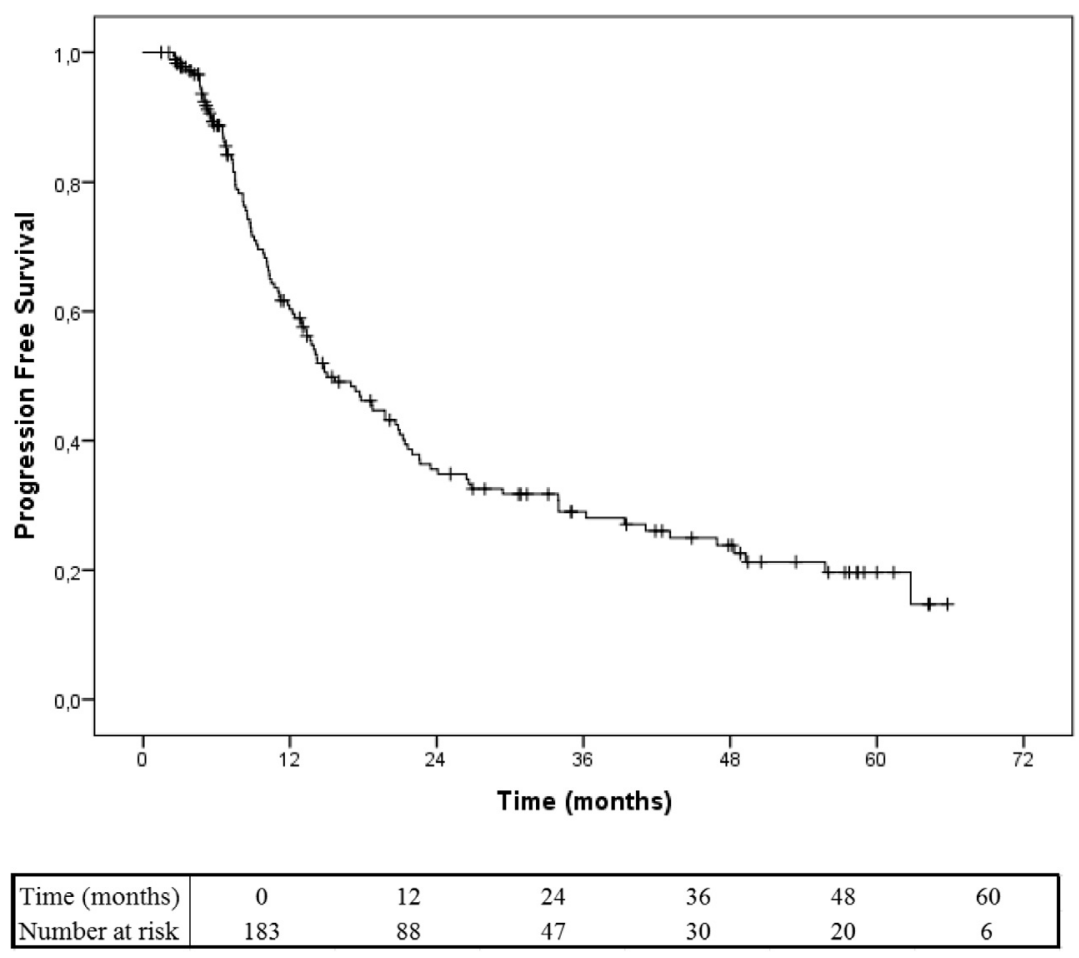

Fig. 2. Kaplan-Meier curve showing Progression Free Survival (PFS) for the entire cohort.

than three months after radiotherapy. Of those patients with severe dyspnoea one patient had atrial fibrillation, pneumonia, cardiac failure and lung fibrosis, in one patient a radiation pneumonitis was suspected, lung fibrosis was the cause in another patient and in one patient recurrent disease was suspected.

\section{Discussion}

To the best of our knowledge, this is the first study investigating the INF rate in NSCLC with selective nodal irradiation using IMRT. Although it was previously shown that selective nodal RT in the $3 \mathrm{D}$-CRT era resulted in an INF rate of about $2 \%$, these achievements may not be extrapolated to IMRT as the dose to adjacent lymph nodes are lower. We observed an INF rate of 2.2\% (actuarial 2year risk 2.4\%; 95\% CI 0.0-5.7), which is equal to INF after 3DCRT (2.0-2.3\%). Previous studies have shown that selective nodal irradiation does not result in a higher percentage INF in comparison with elective nodal irradiation [13,14]. De Ruysscher et al. [13] reported an INF of $2.0 \%$ in patients treated with selective nodal irradiation using 3D-CRT. Comparable results were seen in a study of Belderbos et al. [14] with an INF-rate of 2.3\%. Also for locally advanced small cell lung cancer (SCLC), selective nodal RT has proven to be safe. In a prospective study, van Loon et al. observed an INF rate of $3 \%$, which as similar to the $2 \%$ incidence in a retrospective series from MD Anderson [32,33]. In a larger study, Reymen et al. found out field INF in $1.7 \%$ of the patients with SCLC [34].

We have not directly compared IMRT and 3D-CRT plans in our study. However 3D-CRT plans consists usually of 3 photon beams (AP, PA and lateral) whereas in the IMRT plan seven to nine coplanar and a maximum of two non-coplanar photon beams were used. This leads to the IMRT plans being more conformal and giving a lower dose to adjacent lymph nodes than 3D-CRT. Studies have confirmed that IMRT gives a more conformal dose to the target volume with lower doses to the organs at risk [23,25-27]. Moreover Fleckenstein et al. showed in their study that the dose to lymph nodes adjacent to the CTV is significantly lower when IMRT is compared to 3D-CRT which translates into a lower tumour control probability [28].

The definition of INF differs between the studies. We defined an INF as a nodal recurrence without local recurrence or distant metastases. We considered out of field as outside the CTV, whereas in other studies "out of field" was defined as outside of the PTV. In the present study one INF was outside the CTV and outside the PTV. We used the atlas of Chapet et al. [31] to assess recurrences in specific lymph node levels. There could be anatomical changes due to the radiotherapy but they seem less relevant in nodal recurrences as local recurrences would in the lung.

A portion of the patients in this study were treated with seqCRT. Patients were included in this study at the day of the first radiation fraction. If patients showed progression or if the WHO-PS declined during the chemotherapy patients were not referred for radical treatment and thereby not enrolled in this study. This might have influenced outcome in the sequential group with regard to OS and PFS, however we do not believe that it would have a great influence on the incidence of isolated nodal failure.

The acute toxicity when using IMRT is comparable with the acute toxicity using 3D-CRT.

Although FU was according to the regional guidelines, there might have been some difference between the referring hospitals regarding timing and manner of FU which could influence the timing of the nodal recurrence. Asymptomatic nodal recurrences could have been missed or diagnosed on a later time point. Only seven patients (3.8\%) experienced a nodal recurrence with distant metastases without a local recurrence. It can obviously not be excluded that in these cases the nodal recurrence is the source of the distant metastases.

Although the incidence of INF is limited, the addition of EBUSTBNA mapping and other imaging modalities may have additional value to staging with FDG-PET-CT to further decrease the number of geographical misses [35,36].

In conclusion, FDG-PET-CT based selective nodal irradiation with IMRT results in an INF-rate of $2.2 \%$, which is comparable to INF-rates after 3D-CRT, and may thus be considered safe. 


\section{Funding}

None.

\section{Conflict of interest}

None declared.

\section{Acknowledgement}

Authors acknowledge financial support from the Kankeronderzoekfonds Limburg (travel grant).

\section{References}

[1] Jemal A, Bray F, Center M, Ferlay J, Ward E, Forman D. Global cancer statistics. CA - Cancer J Clin 2011;61:69-90.

[2] Siegel R, Naishadham D, Jemal A. Cancer statistics, 2013. CA - Cancer J Clin 2013;63:11-30.

[3] Aupérin A, Péchoux Cl, Rolland E, Curran W, Furuse K, Fournel P, et al. Metaanalysis of concomitant versus sequential radiochemotherapy in locally advanced non-small-cell lung cancer. J Clin Oncol 2010;28:2181-90.

[4] Dutch guideline non small cell lung cancer. <http://www.oncoline.nl/nietkleincellig-longcarcinoom>; 2015.

[5] Ramnath N, Dilling T, Harris L, Kim A, Michaud G, Balekian A, et al. Treatment of stage III non-small cell lunmg cancer: diagnosis and management of lung cancer, 3rd ed: American college of chest physicians evidence-based clinical practice guidelines. Chest 2013;143:e314s-40s.

[6] Vansteenkiste DDR W, Eberhardt E, Lim E, Senan S, Felip E, Peters S, ESMO Guidelines Working Group. Early and locally advanced non-small-cell lung cancer (NSCLC): ESMO Clinical Practice Guidelines for diagnosis, treatment and follow-up. Ann Oncol 2013;24:vi89-98.

[7] Walraven I, Heuvel MVD, Diessen JV, Schaake E, Uyterlinde W, Aerts J. Longterm follow-up of patients with locally advanced non-small cell lung cancer receiving concurrent hypofractionated chemoradiotherapy with or without cetuximab. Radiother Oncol 2016:118.

[8] Bradley JD, Paulus R, Komaki R, Masters G, Blumenschein G, Schild S, et al. Standard-dose versus high-dose conformal radiotherapy with concurrent and consolidation carboplatin plus paclitaxel with or without cetuximab for patients with stage IIIA or IIIB non-small-cell lung cancer (RTOG 0617): randomised, two-by-two factorial phase 3 study. Lancet Oncol 2015;16:187-99.

[9] Diessen JV, Chen C. Heuvel MVD, Belderbos J, Sonke J. Differential analysis of local and regional failure in locally advanced non-small cell lung cancer patients treated with concurrent chemoradiotherapy. Radiother Oncol 2016;118:447.

[10] Belderbos J, Kepka L, Kong F-M, Martel M, Videtic G, Jeremic B. Report from the international atomic energy agency (IAEA) consultants' meeting on elective nodal irradiation in lung cancer: non-small-cell lung cancer (NSCLC). Int Radiat Oncol Biol Phys 2008;72:335-42.

[11] Ruysscher DD, Faivre-Finn C, Nestle U, Hurkmans C, Péchoux Cl, Price A, et al. European organisation for research and treatment of cancer recommendations for planning and delivery of high-dose, high-precision radiotherapy for lung cancer. J Clin Oncol 2010;28:5301-10.

[12] Yuan S, Sun X, Li M, Yu J, Ren R, Yu Y, et al. A randomized study of involvedfield irradiation versus elective nodal irradiation in combination with concurrent chemotherapy for inoperable stage III nonsmall cell lung cancer. Am J Clin Oncol 2007;30:239-44.

[13] Ruysscher DD, Wanders S, Haren EV, Hochstenbach M, Geeraedts W, Utama I et al. Selective mediastinal node irradiation based on FDG-PET scan data in patients with non-small-cell lung cancer: a prospective clinical study. Int J Radiat Oncol Biol Phys 2005;62:988-94.

[14] Belderbos J, Heemsbergen W, Jaeger KD, Baas P, Lebesque J. Final results of a phase I/II dose escalation trial in non-small-cell lung cancer using threedimensional conformal radiotherapy. Int J Radiat Oncol Biol Phys 2006;66:126-34.

[15] Kepka L, Bujko K, Siwinska AZ. Risk of isolated nodal failure for non-small cell lung cancer (NSCLC) treated with the elective nodal irradiation (ENI) using 3Dconformal radiotherapy (3D-CRT) techniques - a retrospective analysis. Acta Oncol 2008;47:95-103.
[16] Sanuki-Fujimoto N, Sumi M, Ito Y, Imai A, Kagami Y, Sekine I, et al. Relation between elective nodal failure and irradiated volume in non-small-cell lung cancer (NSCLC) treated with radiotherapy using conventional fields and doses. Radiother Oncol 2009;91:433-7.

[17] Kolodziejczyk M, Bujko K, Michalski W, Kepka L. Incidence of isolated nodal failure in non-small cell lung cancer patients included in a prospective study of the value of PET-CT. Radiother Oncol 2012;104:58-61.

[18] Kepka L, Maciejewski B, Withers R. Does incidental irradiation with doses below 50 Gy effectively reduce isolated nodal failure in non-small-cell lung cancer: dose-response relationship. Int $\mathrm{J}$ Radiat Oncol Biol Phys 2009;73:1391-6.

[19] Withers R, Peters L, Taylor J. Dose-response relationship for radiation therapy of subclinical disease. Int J Radiat Oncol Biol Phys 1995;34:353-9.

[20] Bezjak A, Rumble R, Rodrigues G, Hope A, Warde P. Intensity-modulated radiotherapy in the treatment of lung cancer. Clin Oncol 2012;24:508-20.

[21] Govaert S, Troost E, Schuurbiers O, Geus-Oei L-Fd, Termeer A, Span P, et al. Treatment outcome and toxicity of intensity-modulated (chemo) radiotherapy in stage III non-small cell lung cancer patients. Radiat Oncol 2012;7.

[22] Sura S, Gupta V, Yorke E, Jackson A, Amols H, Rosenzweig K. Intensitymodulated radiation therapy (IMRT) for inoperable non-small cell lung cancer: the Memorial Sloan-Kettering Cancer Center (MSKCC) experience. Radiother Oncol 2008;87:17-23.

[23] Lievens Y, Nulens A, Gaber MA, Defraene G, Wever WD, Stroobants S, et al. Intensity-modulated radiotherapy for locally advanced non-small-cell lung cancer: a dose-escalation planning study. Int J Radiat Oncol Biol Phys 2011:80:306-13.

[24] Jiang Z-Q, Yang K, Komaki R, Wei X, Tucker S, Zhuang Y, et al. Long-term clinical outcome of intensity-modulated radiotherapy for inoperable nonsmall cell lung cancer: the MD Anderson experience. Int J Radiat Oncol Biol Phys 2012;83:332-9.

[25] Chen A, Li L, Cronin A, Schrag D. Comparative effectiveness of intensitymodulated versus 3D conformal radiation therapy among medicare patients with stage III lung cancer. J Thoracic Oncol 2014;9:1788-95.

[26] Christian J, Bedford J, Webb S, Brada M. Comparison of inverse-planned threedimensional conformal radiotherapy and intensity-modulated radiotherapy for non-small-cell lung cancer. Int J Radiat Oncol Biol Phys 2007;67:735-41.

[27] Bree L, Hinsberg MV, Veelen LV. High-dose radiotherapy in inoperable nonsmall cell lung cancer: comparison of volumetric modulated arc therapy, dynamic IMRT and 3D conformal radiotherapy. Med Dosim 2012;37:353-7.

[28] Fleckenstein J, Eschler A, Kremp K, Kremp S, Rübe C. Dose distribution and tumor control probability in out-of-field lymph node stations in intensity modulated radiotherapy (IMRT) vs 3D-conformal radiotherapy (3D-CRT) of non-small-cell lung cancer: an in silico analysis. Radiat Oncol 2015;10.

[29] Baardwijk AV, Reymen B, Wanders S, Borger J, Öllers M, Dingemans A-M, et al. Mature results of a phase II trial on individualised accelerated radiotherapy based on normal tissue constraints in concurrent chemo-radiation for stage III non-small-cell lung cancer. Eur J Cancer 2012;48:2339-46.

[30] Baardwijk AV, Wanders S, Boersma L, Borger J, Öllers M, Dingemans A-M, et al. Mature results of an individualized radiation dose prescription study based on normal tissue constraints in stages I to III non-small-cell lung cancer. J Clin Oncol 2010;28:1380-6.

[31] Chapet O, Kong F-M, Quint L, Chang A, Haken RT, Eisbruch A, et al. CT-based definition of thoracic lymph node stations: an atlas from the university of Michigan. Int J Radiat Oncol Biol Phys 2005;63:170-8.

[32] Shirvani S, Komaki R, Heymach J, Fossella F, Chang J. Positron emission tomography/computed tomography-guided intensity-modulated radiotherapy for limited-stage small-cell lung cancer. Int J Radiat Oncol Biol Phys 2012;82:e91-7.

[33] Loon JV, Ruysscher DD, Wanders R, Boersma L, Simons J, Oellers M, et al. Selective nodal irradiation on basis of (18)FDG-PET scans in limited-disease small-cell lung cancer: a prospective study. Int J Radiat Oncol Biol Phys 2010;77:329-36.

[34] Reymen B, Loon JV, Baardwijk AV, Wanders R, Borger J, Dingemans AM, et al. Total gross tumor volume is an independent prognostic factor in patients treated with selective nodal irradiation for stage I to III small cell lung cancer. Int J Radiat Oncol Biol Phys 2013;85:1319-24.

[35] Peeters S, Dooms C, Baardwijk AV, Dingemans A, Martinussen H, Vansteenkiste J et al. Selective mediastinal node irradiation in non-small cell lung cancer in the IMRT/VMAT era: How to use E(B)US-NA information in addition to PET-CT for delineation? Radiother Oncol 2016.

[36] Peerlings J, Troost EGC, Nelemans PJ, Cobben DCP, Boer JCJd, Hoffmann AL, et al. The diagnostic value of MRI in determining the lymph node status in patients with non-small cell lung cancer: a meta-analysis. Radiology. (Submitted). 